\author{
Aleksandra Kuligowska \\ Wydział Historii \\ Uniwersytet Warszawski \\ ORCID 0000-0001-9077-3207 \\ a.kuligowska6@uw.edu.p1
}

\title{
Dialog kultur naukowych. Teoretyczne koncepcje metody historycznej Brygidy Kürbis w kontekście niemieckojęzycznej refleksji nad uprawianiem historii
}

Brygida Kürbis, której teoretycznym koncepcjom dotyczącym badań źródeł historycznych poświęcony jest ten artykuł, niewątpliwie należała do grona najwybitniejszych historyków mediewistów powojennej Polski. Przez całe życie uczona związana była z uniwersytetem poznańskim - od 1955 roku noszącym nazwę Uniwersytet imienia Adama Mickiewicza w Poznaniu. W pracy badawczej poświęciła się przede wszystkim polskiej historiografii średniowiecznej, w tym najstarszym jej dziełom, a w dalszej fazie twórczości naukowej dziejom przemian mentalności chrześcijańskiej w średniowiecznej Polsce. Znakomitą część jej dorobku stanowią także edycje źródeł w serii Monumenta Poloniae Historica oraz Monumenta Sacra Polonorum. Równolegle wypracowała podstawy metodologiczne oryginalnej teorii źródłoznawstwa i nauk pomocniczych historii, W roku 1969 objęła funkcję kierownika zakładu naukowego, który istnieje do dziś ${ }^{1}$.

Por. J. Kolbuszewska, Kobiety w drodze na naukowy Olimp... Akademicki awans polskich historyczek (od schyłku XIX wieku po rok 1989), Łódź 2020, s. 295-297; autorka wskazała, że Brygida Kürbis jako jedna z nestorek historyczek poznańskich od 1969 roku kierowała Zakładem Nauk Pomocniczych Historii. Tymczasem Kürbis już od 1stycznia 1966 roku kierowała zakładem, którego nazwa brzmiała: Zakład Historii Kultury Średniowiecznej i Źródłoznawstwa. Funkcjonował on przy katedrze Historii Powszechnej Średniowiecza. Dopiero w 1969 roku został przekształcony 
Ważnym elementem rozwoju intelektualnego Brygidy Kürbis były jej studia na uniwersytecie we Fryburgu Bryzgowijskim dokąd doprowadziły ją tragiczne losy wojenne - utrata rodziców zamordowanych przez nazistów, z którymi mieszkała w Wolnym Mieście Gdańsku. Słuchając wykładów wielu wybitnych uczonych, w tym takich sław jak Gerd Tellenbach czy Martin Heidegger ${ }^{2}$ po raz pierwszy zetknęła się z myślą filozoficzną, która zainspirowała jej własne rozważania, dotyczące teoretycznych podstaw uprawianych przez nią badań. Wysiłek rozpoznania zachowanych we fryburskim archiwum uniwersyteckim śladów obecności Kürbis na uczelni podjął jeden z jej uczniów Rafał Witkowski. W aktach personalnych ówczesnej studentki fakultetu filozoficznego zachowały się dwa indeksy z semestru letniego 1944 i zimowego 1945/46 roku³. Dają one informację o tym, na jakie wykłady zapisała się wówczas Brygida Kürbis. Uczęszczała m. in. na seminarium historyczne Gerharda Rittera, którego cechowała duża rozpiętość zainteresowań badawczych od późnego średniowiecza aż po historię najnowszą. W 1925 roku opublikował biografię Marcina Lutra, którą zresztą sukcesywnie rewidował w toku kolejnych wznowień, wydawanych jeszcze po II wojnie światowej. W czasie studiów we Fryburgu Kürbisówna uczęszczała również na jego wykłady dotyczące renesansu i reformacji oraz rewolucji francuskiej. Drugie seminarium historyczne, na które się zapisała, przynajmniej w dwóch semestrach prowadził Gerd Tellenbach, mediewista zajmujący się głównie okresem wczesnego i późnego średniowiecza, powołany na katedrę we Fryburgu w 1944 roku. W tym czasie miał już na koncie trzy rozprawy dotyczące centralnych dla niego tematów badawczych: sporu o inwestyturę oraz wczesnych dziejów Rzeszy Niemieckiej4. Kürbisówna słuchała jego wykładów poświęconych Europie w XIII i XIV wieku, sporowi o inwestyturę oraz historii Hohenstaufów. Zapisała się także na filozofię średniowieczną, filozofię nowożytną i wprowadzenie do psychologii prowadzone przez Vinzenza Rüfnera. Punktem ciężkości zainteresowań tego uczonego oprócz filozofii państwa była filozofia średniowieczna oraz antropologia filozoficzna. Kürbisówna uczestniczyła również w seminariach i proseminariach prowadzonych przez znakomitych filologów, takich jak: wydawca Horacego, a później Cycerona, Karl Büchner (Horacy, Cycerona De officiis), czy romanista Hugo Friedrich (francuski romantyzm, klasyka francuska, Montesquieu i Rousseau, wprowadzenie do

w samodzielny Zakład Nauk Pomocniczych Historii, a od 1982 roku, również pod kierownictwem Brygidy Kürbis, nosił nazwę Zakład Źródłoznawstwa i Nauk Pomocniczych Historii. To istotne zastrzeżenie, bo właśnie koncepcja źródłoznawstwa była ważnym wkładem Kürbis w polską metodykę historyczną, a nazwa zakładu, którym kierowała to właśnie odzwierciedlała.

2 Więcej na temat życiorysu B. Kürbis zob. R. Witkowski, Brygida Kürbis (1921-2001), w: B. Kürbis, Cztery eseje o źródłoznawstwie, wstęp i dobór tekstów Rafał Witkowski, Poznańskie Towarzystwo Przyjaciół Nauk, Poznań 2007, s. 9-35.

3 Skany otrzymałam dzięki uprzejmości Rafała Witkowskiego. Więcej na ten temat znajdzie się w jego artykule przygotowywanym do tomu poświęconego badaczce z okazji dwudziestej rocznicy śmierci, por. przypis 10 .

4 Zob.: G. Tellenbach, Libertas. Kirche und Weltordnung im Zeitalter des Investiturstreites, Kohlkammer, Stuttgart 1936; idem, Königtum und Stämme in der Werdezeit des Deutschen Reiches, Böhlau, Weimar 1939; idem, Die Entstehung des Deutschen Reiches. Von der Entwicklung des fränkischen und deutschen Staates im 9. und 10. Jahrhundert, Verlag Georg D.W. Callwey, München 1940. 
romanistyki). Francuski kształciła na ćwiczeniach prowadzonych wówczas przez romanistów, m.in. hrabinę Elisabeth Mandelsloh (stylistyka francuska, fonetyka francuska, ćwiczenia translatologiczne na tekstach Voltaire'a) i Maurice'a Jordy (konwersacje).

Doświadczenia intelektualne zdobyte na niemieckim uniwersytecie niewątpliwie pozwoliły badaczce na docenienie i wykorzystanie w jej późniejszej koncepcjach pojawiających się na gruncie humanistyki nowych ujęć teoretycznych Foucaulta i Bachtina. W niniejszym artykule podejmę jedynie próbę rozpoznania jej dialogu z niemiecką myślą teoretyczną. Tak wąsko postawiony cel wynika również z nadal skromnego stanu badań nad dorobkiem Brygidy Kürbis. Zaliczyć doń można charakterystykę wszechstronnych rozważań uczonej, przedstawioną przez Gerarda Labudę w księdze pamiątkowej, poświęconej jej z okazji trzydziestolecia pracy naukowej ${ }^{5}$. Pokrótce traktuje o tym również wstęp tego autora, poprzedzający drugi tom prac zebranych Kürbis, który ukazał się w 2001 roku$^{6}$. W tym samym roku została wydana także księga pamiątkowa na uroczyste odnowienie doktoratu uczonej, zawierająca bibliografię jej prac oraz wprowadzenie Jacka Wiesiołowskiego, w którym po krótce omówił on drogę intelektualną badaczki ${ }^{7}$. Brygida Kürbis nie ujrzała jednak ani jednej ze wspomnianych książek. Zmarła 5 listopada 2001 roku, krótko przed ich ukazaniem się drukiem. Nieco światła na drogę badawczą uczonej rzuca wstęp Rafała Witkowskiego, poprzedzający edycję wybranych przez niego tekstów Kürbis, zawartych w trzynastym tomie serii wydawanej przez Poznańskie Towarzystwo Przyjaciół Nauk pt. „Klasycy Nauki Poznańskiej”». Jedyne jak dotąd rozważania na temat koncepcji metodycznych badaczki przedstawił jej uczeń Edward Skibiński w artykule omawiającym jej projekt źródłoznawstwa9 ${ }^{9}$ Tę lukę badawczą, w dotychczasowych dociekaniach nad dorobkiem Brygidy Kürbis ma szansę wypełnić tom przygotowywany z okazji dwudziestej rocznicy śmierci uczonej, którego druk zaplanowano na listopad $2021 \mathrm{roku}^{10}$. Inicjatorami, przy współudziale Danuty Zydorek, są Edward Skibiński i Paweł Stróżyk, którzy od wielu lat prowadzą funkcjonujące na Wydziale Historii UAM otwarte Seminarium Źródłoznawcze im. Brygidy Kürbis.

5 G. Labuda, ,Księga uczonych” dla Uczonej w księgach, w: Mente et litteris. O kulturze i spoteczeństwie wieków średnich, Wydawnictw Naukowe Uniwersytetu im. Adama Mickiewicza w Poznaniu, Poznań 1984, s. 7-20.

6 Idem, Uczona zbiera plony swego naukowego siewu, w: B. Kürbis, Na progach historii II. O świadectwach do dziejów kultury Polski średniowiecznej, Wydawnictwo Poznańskie, Poznań 2001, s. 5-8. Tom pierwszy ukazał się w roku 1994, został zaopatrzony wyłącznie w jednostronicowe wprowadzenie samej autorki, zob.: B. Kürbis, Na progach historii. Prace wybrane, Wydawnictwo Abos, Poznań 1994.

7 J. Wiesiołowski, Scriptura custos memoriae, w: D. Zydorek (red.): Scriptura custos memoriae. Prace historyczne, Instytut Historii UAM, Poznań 2001, s. XXIX-XXXIV.

8 Zob. R. Witkowski, Brygida Kürbis...

9 E. Skibiński, Projekt źródłoznawstwa wedtug Brygidy Kürbis, „Historia Slavorum Occidentis” 2012, t. 1, z. 2, s. 11-21.

10 Opublikowane zostaną w nim m.in. niewydane dotąd artykuły dotyczące problemów społecznych w badaniach Brygidy Kürbis (autor: J. Wyrozumski), duchowości średniowiecznego chrześcijaństwa w opinii Brygidy Kürbis (autor: J.A. Spież), dziejopisarstwa polskiego średniowiecza w badaniach Brygidy Kürbis (autorka: J. Krzyżaniakowa). 
Czytelnikowi należy się też wyjaśnienie co do wybranego przeze mnie umieszczonego w tytule sformułowania dialog kultur. Jeżeli przyjąć wąskie założenie, że dialog zakłada wymianę pomiędzy przynajmniej dwoma aktorami, w tym wypadku między Brygidą Kürbis i przedstawicielami niemieckojęzycznych badaczy, wówczas takie określenie wobec przedstawionych przeze mnie analiz może budzić sprzeciw. Nasuwa się bowiem skojarzenie $\mathrm{z}$ transferem idei odbywającym się w jednym kierunku. Moje rozumienie dialogu zakłada tu jednak perspektywę diachroniczną. Dialogowość jest tu zatem „elementem sytuacji dialogicznej w ciągu procesu historycznego" ${ }^{11}$. Tak rozumiany dialog kultur odrzuca pojęcie zwyczajowego jednostronnego transferu jako błędnego założenia.

Przedstawienie horyzontu poznawczego Brygidy Kürbis wymagałoby zapewne wieloletnich studiów nad jej dorobkiem. W moim artykule nie stawiam sobie takich celów, bo i zadaniem nauki nie jest mówienie o wszystkim i opanowanie wszystkiego. Analizując teksty Kürbis, odnoszące się do zagadnień metodologicznych, ograniczę się zatem do próby odpowiedzi na pytanie, jak na jej koncepcje z zakresu teorii historii i metodyki historycznej mogły wpłynąc idee, które na tym polu wypracowali historycy niemieckojęzyczni. W artykule omawiam też jedną z nadal podstawowych kategorii współczesnej nauki historycznej w Polsce - źródłoznawstwo - która mimo swej popularności, wyjąwszy dociekania Brygidy Kürbis, jak pokazano wyżej, nie zajmuje zbyt wielu badaczy. Choć często używa się tego terminu, a do tego funkcjonuje on w nazwie wielu zakładów naukowych na wydziałach historycznych polskich uniwersytetów, w dalszym ciągu bywa różnie rozumiany. Zwykle źródłoznawstwo traktuje się jako sposób analizy źródeł historycznych. Inaczej rozumiała je Brygida Kürbis. W artykule koncentruję się więc na podstawowych dla badaczki kategoriach z zakresu metody historycznej takich jak źródłoznawstwo, a także nauki pomocnicze historii.

\section{Źródłoznawstwo}

Źródłoznawstwo, którego oryginalną koncepcję Brygida Kürbis forsowała już od lat pięćdziesiątych, stało się jednym z tych zagadnień, które stale rozwijała w swoim dorobku pisarskim. Do tego pojęcia wracała zarówno w tekstach poświęconych metodyce historycznej, jak i koncentrujących się wokół jej praktyki badawczej z zakresu mediewistyki. Należy więc rozpocząc od tego, co pod pojęciem źródłoznawstwa rozumiała uczona. Wolno chyba przyjąć, że termin ten pojawił się w naszej rodzimej historiografii jako kalka niemieckiego słowa Quellenkunde, oznaczającego pierwszy etap pracy badawczej historyka, zwany obecnie heurezą ${ }^{12}$. Takie jego rozumienie znajdziemy w wielu niemieckich podręcznikach metod historycznych, korzeniami sięgających jeszcze XIX wieku ${ }^{13}$. Spośród pierwszych polskich historyków pojęciu temu więcej uwagi poświęca

\footnotetext{
11 E. Skibiński, Projekt źródłoznawstwa..., s. 20.

12 W takim znaczeniu przyjmował je np. przedstawiciel starszego pokolenia krakowskiej szkoły historycznej Józef Szujski.

13 Por. klasyczne prace takie jak: J.G. Droysen, Historik. Vorlesungen über Enzyklopädie und Methodologie der Geschichte, R. Oldembourg, München-Berlin 1937; E. Bernheim, Lehrbuch der historischen Methode und der Geschichtsphilosophie, Duncker \& Humblot, Leipzig 1908, ale
} 
jedynie ta autorstwa Kazimierza Sochaniewicza, który źródłoznawstwo nazywa zamiennie heurezą ${ }^{14}$. Jak się zdaje, po raz pierwszy słowo to pojawiło się u nas w thumaczeniu dzieła Heinricha Zeissberga, dokonanym przez Adolfa Pawińskiego w 1877 roku $^{15}$. Autor słowami thumacza ubolewał nad tym, że ruch humanistyczny w Polsce nie mógł poświęcić należytej uwagi polskim źródłom, stąd „nie ukazało się dzieło, które by do źródłoznawstwa należało", rozumianego tu jako katalog źródeł, pomocny przy pracy historycznej.

Brygida Kürbis nie zawężała źródłoznawstwa do heurezy. Jak sama na to wskazywała, terminem tym posługiwała się jedynie w znaczeniu wyższego etapu krytyki źródłowej i jej dopełnienia jako interpretacji podstawy źródłowej ${ }^{16}$. Nowatorstwo Kürbis polegało na tym, że źródło historyczne potraktowała jako fakt historyczny: „Przeniesienie metody genetycznej z faktów na same źródła historyczne stanowiło o istotnym postępie poznawczym. Nauczyliśmy się (i wciąż jeszcze uczymy) oddzielać motywacje kronikarskie od motywacji przyczyn, okoliczności, jakie zachodziły wśród osób i sytuacji dziejowych. Nauczyliśmy się interpretować źródła »osobno«, objaśniać je i analizować jako wyodrębniony przedmiot badań" ${ }^{17}$. Klasyczna historiografia ujmowała źródło jako środek do uzyskania wiedzy o przeszłości. Kürbis odwróciła tę koncepcję, zmieniając paradygmat badawczy $z$ historycznego na źródłoznawczy. W tym sensie rekonstrukcja historyczna dotyczy źródła, jego funkcjonowania itd., a nie tylko tego, o czym ono mówi. Źródło w takim ujęciu przestaje być traktowane jako interesujący historyka fragment rocznika czy kroniki, lecz jest rozumiane jako całościowy komunikat. Trudno więc zgodzić się z opinią Tomasza Jasińskiego, uważającego, że źródłoznawstwo u Brygidy Kürbis oznacza jedynie „,pogłębioną egzegezę źródeł historycznych”18.

Jak zatem należy stosować metodę źródłoznawczą w ujęciu Brygidy Kürbis? Fragment np. kroniki, który jest historykowi potrzebny do rekonstrukcji historycznej, nie

i późniejsze podręczniki dla studentów o charakterze wprowadzającym np.: A. v. Brandt, Werkzeug des Historikers, Kohlhammer, Stuttgart 1958.

14 K. Sochaniewicz, Nauka Historji. Wskazówki do samokształcenia, nakład i własność K.S. Jakubowskiego, Lwów 1928, s. 83. Pojęcia nie notuje M. Handelsman, Historyka, wyd. 2 popr. i uzup., Gebethner i Wolff, Warszawa 1928. Podobnie pojęcia tego nie zawiera podręcznik Władysława Konopczyńskiego przygotowany do druku w roku 1948, jednak zablokowany z powodów politycznych i opublikowany dopiero przed kilku laty w opracowaniu i ze wstępem Macieja Janowskiego: W. Konopczyński, Historyka, Oficyna Wydawnicza ASPRA-JR, Warszawa 2015.

15 H. Zeissberg, Dziejopisarstwo polskie wieków średnich, Skł. Gł. Gebethner i Wolff, Warszawa 1877, s. 2.

16 B. Kürbis, Metody źródłoznawcze wczoraj i dziś, w: Pamiętnik XII Powszechnego Zjazdu Historyków Polskich. 17-20 września 1979 roku, cz. 1, Uniwersytet Śląski, Katowice 1979, s. 91. Brygida. Kürbis napisała jeszcze jeden artykuł o tym samym tytule. Ten drugi, o innej treści, został opublikowany w „Studiach Źródłoznawczych”, zob. B. Kürbis, Metody źródłoznawcze wczoraj i dziś, „Studia Źródłoznawcze” 1979, t. 24, s. 93-96 i przedrukowany w jej pracach wybranych z 1994 roku.

17 B. Kürbis, Metody źródtoznawcze wczoraj i dziś, w: eadem, Na progach historii, s. 264.

18 T. Jasiński, Nauki pomocnicze historii czy źródłoznawstwo - terminologia czy metody badawcze, w: A. Jaworska, B. Trelińska (red.), Od genealogii do historii społecznej, Wydawnictwo DiG, Warszawa 2011, s. 181. 
może być traktowany jako samodzielna, wyodrębniona z niej cząstka bądź jedynie jako świadectwo badanego wydarzenia. Wówczas takie podejście nawiązuje do sztywnych reguł dyplomatyki, która poucza, że w dokumencie wszystko ma swoje określone miejsce. To ustatycznienie źródła prowadzi do jedynie powierzchownej analizy: „W zapale krytyki zapomniano honorować robotę dziejopisarską w kronikach i biografiach, stosując i do nich sztywne »sądowe« kryteria dyplomatyczne. Nie odróżniano prawdy o faktach od prawdy poglądów, które od samego świtu istnienia literatury w dziejach ludzkich szukały sobie innych środków wyrazu niż świadectwo prawa"19. Źródłoznawstwo w ujęciu Kürbis nakazuje więc badać przykładowy fragment kroniki jako cząstkę wypowiedzi kronikarza, która sama jest zdarzeniem historycznym. Co ciekawe, dla niemieckojęzycznych reprezentantów historyzmu grzech główny historyków wobec metody przejawiał się w zastępowaniu jednych etapów procedury badawczej historyka przez drugie. Działo się tak, gdy przykładowo interpretacja wdzierała się na miejsce krytyki ${ }^{20}$. Brygida Kürbis, jak można przypuszczać, dostrzega tę sytuację, gdy metody krytyczne, w tym wypadku niemal usamodzielnionej dyplomatyki, zastępują, a przez to zniekształcają interpretację.

Prace Brygidy Kürbis, traktujące o metodzie historycznej czy o źródłoznawstwie, nie imponują objętością. Jednak za pozornie skromnym aparatem naukowym i skondensowanymi wypowiedziami na ten temat kryją się nowatorskie pomysły teoretyczne, będące wynikiem jej szerokiej erudycji, a co za tym idzie, znakomitej orientacji we współczesnych koncepcjach z zakresu teorii historii. Zasadniczą trudność przy lekturze tekstów Brygidy Kürbis sprawia nieujawnianie przez autorkę źródeł swojej erudycji. Jednej z przyczyn takiego jej podejścia można by upatrywać w momencie historycznym dla metodologii i metodyki historii niezbyt przychylnym. W PRL-owskiej historiografii, przynajmniej na początku, nie uchodziło powoływanie się zwłaszcza na zachodnioniemieckie badania. Do tego w epoce, w której modne i pociągające dla historyków stały się prądy marksizujące, przeciwnikiem kierunku, jaki w swoich rozważaniach obrała Brygida Kürbis, okazała się również historiografia pozytywistyczna. W koncepcjach przedstawicieli tego kierunku w imię naukowości, której przejawem jest dostosowanie historii do nauk ścisłych, źródłoznawstwo jawi się jako niepotrzebna zabawa. Udatnie zastąpić ją można poszukiwaniem praw w historii poprzez naśladownictwo nauk przyrodniczych.

\section{Kryzys metody i nowe klasyfikacje źródel historycznych}

Jedna z pierwszych krótkich wypowiedzi na ten temat dotyczy metodyki niemieckich badań źródłowych i ukazała się w „Kwartalniku Historycznym” z roku 1954²1. Na niewiele ponad pięciu stronach Brygida Kürbis wyłożyła własne poglądy, dotyczące nowszych badań niemieckich $\mathrm{z}$ dziedziny tzw. nauk pomocniczych historii. W tytule

\footnotetext{
19 B. Kürbis, O założeniach i metodzie edycji historycznych i literackich, w: eadem, Cztery eseje..., s. 75.

20 Por. E. Bernheim, Lehrbuch ..., s. 562-566.

21 B. Kürbis, Nowsze badania niemieckie z dziedziny tzw. nauk pomocniczych historii. Kryzys metody, „Kwartalnik Historyczny” 1954, R. 61, s. 386-391.
} 
tego, jak ujęła to sama autorka, sprawozdania, użyła jednocześnie sformułowania „kryzys metody” w odniesieniu do „burżuazyjnej historiografii zachodnio-niemieckiej”22. Zapewne nieprzypadkowo. O kryzysie w nauce historycznej mówił austriacki mediewista i współpracownik „Monumenta Germaniae Historica” Karl Pivec, w wykładzie inauguracyjnym, wygłoszonym na Uniwersytecie w Insbrucku 30 listopada 1950 roku. Pivec objął wówczas katedrę średniowiecza. Wcześniej pracował jako profesor nadzwyczajny w katedrze nauk pomocniczych historii w Lipsku. Swój wykład drukiem ogłosił w „Mitteilungen des Instituts für Österreichische Geschichtsforschung” dwa lata po odczycie na inauguracji ${ }^{23}$. Mimo że okres ten w polskiej historiografii był mocno naznaczony wdzieraniem się ideologii do badań historycznych Brygida Kürbis nie uległa upolitycznionej standaryzacji, nakazującej cytowanie klasyków marksizmu i leninizmu. Jednakże w tekście o kryzysie metody, choć bardzo krótkim, zarysowała się pewna tendencja, charakterystyczna dla tego czasu, wyrażająca się m.in. w krytyce formalizmu w naukach historycznych. Być może był to zresztą wpływ myśli Gerarda Labudy, dobrze przecież Brygidzie Kürbis znanej. W tym samym roku Labuda przygotuje do druku artykuł poświęcony nowej interpretacji i nowej klasyfikacji źródeł historycznych ${ }^{24}$, w którym daje się zauważyć pewnego rodzaju „marksistowskie ukąszenie”, choć jego poglądy w istocie nie będą przystawały do nurtu nachalnie forsowanego choćby w „Nowych Drogach”. W przypadku tekstu Brygidy Kürbis mamy jednak ciekawą sytuację, w której uczona wykorzystuje nowe trendy w historiografii PRL-u dla budowania własnej koncepcji źródłoznawstwa. Formalny punkt widzenia wiąże się dla niej z czysto zewnętrznym i mechanicznym stosunkiem źródła „do norm prawnych, kancelaryjnych, literackich”. Formalizm przejawiałby się zatem w unieruchomieniu pojęć stosowanych $\mathrm{w}$ historiografii, traktowanych tym samym ahistorycznie. Przyjmowanie, że forma źródła jest raz na zawsze dana i pozostaje niezmienna na przestrzeni dziejów, musiało wykrzywiać ich obraz. Aby zaniechać takiego podejścia, zdaniem uczonej „mało liczącego się z wiecznie zmiennym przebiegiem procesów dziejowych i z ludźmi” 25 , proponuje Kürbisówna zerwanie z dotychczasowym ujęciem źródła jako środka do rekonstrukcji dziejów. Przypomnijmy, że założenie to najpełniej wybrzmiało w Lehrbuch der historischen Methode Ernsta Bernheima, który uczynił je punktem wyjścia do swojej refleksji nad historiografią i którego podręcznik przez długi czas wyznaczał standardy pracy historyka. Jego poglądy jednak z powodów historycznych przemian uległy później pewnemu zapomnieniu ${ }^{26}$. Brygida Kürbis, sprzeciwiając się unieruchomieniu źródła w przestrzeni historii, proponuje potraktować je jako fakt dziejowy, „mający z procesem dziejowym w całym jego przekroju istotne powiązania nie tylko natury

22 B. Kürbis, Nowsze badania niemieckie..., s. 386.

23 K. Pivec, Geschichtswissenschaft von heute, „Mitteilungen des Instituts für Österreichische Geschichtsforschung“ 1952, t. 60, s. 319-334.

24 G. Labuda, Próba nowej systematyki i nowej interpretacji źródeł historycznych, „Studia Źródłoznawcze"1957, t. 1, s. 3-53 [przedruk: G. Labuda, Próba nowej systematyki i nowej interpretacji źródet historycznych: z posłowiem, Wydawnictwo Poznańskie, Poznań 2010].

25 B. Kürbis, Nowsze badania niemieckie..., s. 387.

26 Więcej na temat Ernsta Bernheima i jego koncepcji teoretycznych zob. A. Kuligowska, Auffassung w koncepcji historii Ernsta Bernheima, Wydawnictwo Poznańskie, Poznań 2013. 
formalnej, ale i treściowej”27. Paradoksalnie na postulat ten odpowiadałby historyzm, nawołujący do badania źródeł $\mathrm{w}$ ścisłym powiązaniu z kontekstem, w którym powstały. Z kolei w innym miejscu, w artykule $\mathrm{z}$ drugiej połowy lat siedemdziesiątych, Kürbis powołuje się na badania Bernheima, dotyczące budowy kategorii średniowiecznego światopoglądu $\mathrm{w}$ zgodzie $\mathrm{z}$ ich rozumieniem $\mathrm{z}$ epoki ${ }^{28}$. Zatem niemieckiej klasycznej historiografii burżuazyjnej Brygida Kürbis z jednej strony zarzuca formalizm, by z drugiej wykorzystać jej zdobycze do tworzenia własnych koncepcjach źródłoznawczych.

Podobnie, idąc tropem niemieckich dystynkcji pojęciowych w nauce historycznej, Kurbisówna wyraźnie stawia postulat odróżniania pojęcia metodyki i metodologii historii, traktując tę drugą jako refleksję nad tą pierwszą. Wyraża to choćby w referacie zatytułowanym Methodik, Methodologie, Quellenkritik und Quellenkunde, wygłoszonym przez nią podczas kolokwium berlińskiego, które odbyło się 18 i 19 czerwca 1974 roku ${ }^{29}$. Kürbis zaznacza jednak: „Die Methodologie (als Theorie der historischen Prozesse) ist zwar von der Methodik nicht zu trennen, aber bei analytischen Betrachtung müssen wir die Methodologie sozusagen als den Überbau der quellenkritischen Arbeit betrachten. Erst Erforschung, dann erst Erkenntnis. Tatsächlich jedoch ist historische Erkenntnis ohne eine Erklärung in größeren Zusammenhängen nicht denkbar" ${ }^{30}$.

Brygida Kürbis jeszcze przed opublikowaniem tekstu Gerarda Labudy o klasyfikacji źródeł historycznych przedstawiła swój pogląd na temat podziału źródeł, zaproponowanego przez Hansa Leo Mikoletzky'ego ${ }^{31}$. Austriacki historyk habilitował się na podstawie rozprawy poświęconej relacji cesarza Henryka II wobec Kościoła, szeroko omawiającej zagadnienia heurezy źródłowej ${ }^{32}$. Mikoletzky, co w kontekście jego pracy badawczej odgrywa niebagatelną rolę, był wieloletnim pracownikiem Austriackiego Archiwum Państwowego, by w 1968 roku objąć funkcję dyrektora generalnego tej instytucji. Propozycję jego systematyki źródeł Kürbisówna uznała za „mieszczącą się bez reszty w tradycyjnym systemie”. Jej zdaniem „formalny podział na źródła zamierzone i niezamierzone nie dostarcza metodycznych przesłanek do postępowania poznawczego" "33. Swoją argumentację wsparła przypisem do uwag krytycznych wyrażonych przez Helmuta Plechla na łamach „Deutsches Archiv” w 1952 roku $^{34}$. Autor podpisał się inicjałem „H.P.”, co niewątpliwie pozwoliło przywołać Kürbisównie jego opinię bez

27 B. Kürbis, Nowsze badania niemieckie..., s. 387.

28 B. Kürbis, Sacrum i profanum. Dwie wizje władzy w polskim średniowieczu, „Studia Źródłoznawcze" 1977, t. XXII, s. 19.

29 Struktur und Prozess in der Weltgeschichte - tytuł kolokwium, na podstawie którego opublikowano książkę: E. Engelberg, W. Küttler, Probleme der geschichtswissenschaftlichen Erkenntnis, Akademie Verlag, Berlin 1977.

30 B. Kürbis, Methodik, Methodologie, Quellenkritik und Quellenkunde, w: E. Engelberg, W. Küttler (red.), Probleme..., s. 152.

31 H.L. Mikoletzky, Quellenkunde des Mittelalters, „Mitteilungen des Instituts für Österreichische Geschichtsforschung" 1950, t.. 53, s. 209-227.

32 Idem, Kaiser Heinrich II. und die Kirche, Universum, Wien 1946.

33 Jeszcze dalej poszedł Gerard Labuda, konstatując, że podział Mikoletzky’ego „trzeba określić jako jeden z najgorszych, jakie dotąd w nauce zaprezentowano”. G. Labuda, Próba nowej systematyki..., s. 31.

34 H. Plechl, „Deutsches Archiv für Erforschung des Mittelalters" 1952, nr 9, s. 544. 
podania wprost nazwiska historyka. Plechl, specjalista z zakresu nauk pomocniczych historii, znajdował się wówczas na cenzurowanym. W połowie 1951 roku za brak postawy marksistowskiej zwolniono go z Uniwersytetu Humboldtów, po czym opuścił NRD i podjął pracę naukową we Fryburgu Bryzgowijskim. Tam rok później habilitował się pod kierunkiem Gerda Tellenbacha.

Plechl w krótkiej notce recenzyjnej nie podjął jednak szerszej analizy propozycji Mikoletzky'ego, a jedynie zauważył, że jego podział nie umożliwia jasnej klasyfikacji źródeł. Tak dzieje się choćby, jego zdaniem, w przypadku dokumentów i praw. Na czym polegał podział źródeł w ujęciu Mikoletzky’ego? Wychodząc z podziałów Droysena-Bernheima wyróżniających, mówiąc najogólniej, źródła pośrednie i bezpośrednie mediewista przesunął istotę podziału z aspektowości samego źródła, jako wytworu pracy człowieka, na relację twórca źródła i jego wytwór. Dodam, że chodzi tu o tę relację w takim zakresie, w jakim może być ona poznawana przez analizę źródła. Źródło, zdaniem Mikoletzky’ego, mieści w sobie przekaz, który stał się podstawą jego podziału. Tak więc wyróżnił źródła z a m i e r z o n e (willkürlich wirksame Überlieferung), „der die Absicht und Neigung innewohnt, ihre Anschauung der von ihr erlebten oder gemachten Geschichte festzustellen oder weiterzutragen, ein bestimmtes Bild zu vermitteln" i n i e z a m i e r z o n e (unwillkürlich wirksame Überlieferung), ,die nur für die Erfordernisse der Epoche ihrer Entstehung in Betracht kam und bloß zufällig überdauerte“ ${ }^{635}$. Łatwo zauważyć, że ten sam podział ponad trzydzieści lat później powtórzył Jerzy Topolski, zmieniając jedynie nazwy członów na źródła adresowane i nieadresowane. Zdaniem Kürbis źródłoznawstwo bada źródła jako fakty jednostkowe, ale przy jednoczesnej świadomości, że ludzie posługują się do ich zapisu językiem jako realizacją systemu znakowego (semiotycznego), który nie przekłada się na ten fakt w sposób prosty. Dlatego jej zdaniem „,formalny podział na źródła zamierzone i niezamierzone - pojmowane jednostkowo i podmiotowo - staje się zupełnie bezużyteczny. Istotną bowiem cechą charakteryzującą źródła nie jest mniejsza lub większa świadomość ich twórców, lecz osad społeczny procesu dziejowego, [przejawiający się najdobitniej w interesach klasowych]"36. Takie podejście znajdzie wyraz w późniejszej klasyfikacji Gerarda Labudy, który wyróżnił źródła psycho-, socjo- i ergotechniczne.

Brygida Kürbis w swoich dociekaniach metodycznych broni tezy, że nauka historyczna wypracowała własne metody badawcze i kładzie nacisk na odróżnienie ich od metod filologii, które z punktu widzenia analizy historycznej są formalistyczne. Odcina się zatem od postulatu Ernsta Troeltscha, którego zdaniem ciągła jeszcze nieznajomość średniowiecza wynika $\mathrm{z}$ braku jego filologicznej interpretacji ${ }^{37}$. Wyraziła to w recenzji pracy literaturoznawcy i romanisty Ernsta Roberta Curtiusa pt. Europäische Literatur und lateinisches Mittelalter, krytykując zwłaszcza jego pogląd, że ,jedność kulturalna narodów europejskich ma swoje źródło tylko w rozwijaniu wspólnej łacińskiej szkoły" 38 .

\footnotetext{
35 H.L. Mikoletzky, Quellenkunde..., s. 212-213.

36 B. Kürbis, Nowsze badania niemieckie..., s. 388.

37 Ibidem, s. 388.

38 B. Kürbis, (rec.) E.R. Curtius, Europäische Literatur und lateinisches Mittelalter, „Roczniki Historyczne” 1958, t. XXIV, s. 332.
} 
Zarzuca Curtiusowi brak „pogłębionego studium nad początkami literatur narodowych”. Pisze dalej: „zostały one potraktowane marginesowo i tylko od strony ich stosunku do łaciny. Jest to konsekwentne, skoro autor śledzi średniowieczną kulturę literacką tylko w jednopłaszczyznowej, jakby samorodnej, formalnej ewolucji, skoro zajmuje się tylko jej łacińskim wyrazem. Ileż jednak zagubiło się w takim ujęciu problemów, konfliktów, idei, które stanowiły istotne, historyczne podłoże twórczości literackiej ówczesnego człowieka" 39 . Dla Kürbis praca Curtiusa jest przejawem „,skrajnego »zretoryzowania« badań źródłowych”, co „wynika z zapatrzenia się w formę, z macoszego traktowania treści społecznych" ${ }^{40}$. Dość powiedzieć, że było to odważne wystąpienie niespełna czterdziestoletniej badaczki wobec doświadczonego uczonego, cieszącego się wielką sławą i powszechnie uznawanego za autorytet w dziedzinie literatury średniowiecznej.

\section{Nauki dające poznać źródła historyczne}

Formalizmem jest dla niej również oderwanie badań nauk pomocniczych, w tym np. filologii średniowiecznej, od dociekań ściśle historycznych. Autorka, w zgodzie z koncepcjami Karla Piveca, przyjęła, że ,pod wpływem rozwoju metod badawczych nazwa »nauki pomocnicze« od dawna już nie oddaje istoty rzeczy”. Jak stwierdziła: „badanie źródła za pomocą narzędzi krytycznych paleografii czy dyplomatyki bynajmniej nie jest już funkcją pomocniczą tam, gdzie źródło znajduje się w samym ośrodku zainteresowań

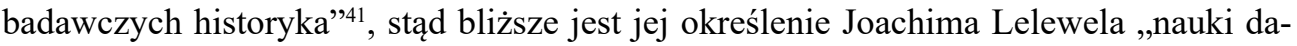
jące poznać źródła historyczne" ${ }^{" 42}$.

Temu zagadnieniu poświęciła Brygida Kürbis odrębne rozważania. We wszystkich swoich wypowiedziach na temat metodyki historycznej naukom pomocniczym historii przyznawała miejsce niebagatelne. We własnej koncepcji tych nauk opierała się na stanowisku Karla Piveca, które uczony wyłożył podczas wykładu inaugurującego objęcie przez niego Katedry Nauk Pomocniczych na Uniwersytecie w Lipsku, 15 marca 1940 roku. Jeszcze w tym samym miesiącu „Mitteilungen des Instituts für Österreichische Geschichtsforschung" opublikowały wykład Hansa Hirscha pt. Methoden und Probleme der Urkundenforschung wygłoszony 28 sierpnia 1938 roku na międzynarodowym kongresie historycznym w Zurychu. Zbieżność w czasie, choć może przypadkowa, jest jednak znamienna. Hans Hirsch, zmarly w sierpniu 1940 roku, był bowiem nauczycielem i mistrzem Piveca, co ten ostatni szczególnie podkreślał.

Już u Hirscha pojawił się postulat traktowania nauk pomocniczych historii jako integralnej części Quellenforschung ${ }^{43}$. Koncepcję tę znacznie rozszerzył jego uczeń Karl Pivec. Sprzeciwił się on zdecydowanie próbie emancypacji nauk pomocniczych, polegającej na coraz dalej posuniętej ich specjalizacji, tak jak usiłował je kształtować Theodor

\footnotetext{
39 Ibidem, s. 332.

40 B. Kürbis, Nowsze badania niemieckie..., s. 389.

41 Ibidem, s. 386-387.

42 Ibidem, s. 387.

43 H. Hirsch, Methoden und Probleme der Urkundenforschung, ,Mitteilungen des Österreichischen Instituts für Geschichtsforschung“ 1939, t. 53, z. 1-2, s. 9.
} 
von Sickel ${ }^{44}$, uznawany za jednego z twórców nowoczesnej dyplomatyki. Choć Pivec nie przeczy, że od strony metodycznej nowa koncepcja historycznych nauk pomocniczych pojawiła się w Wiedniu za sprawą Sickla właśnie, to jednocześnie podkreśla, że na właściwe tory metodycznego rozwoju przestawił je Julius von Ficker ${ }^{45}$, który od 1852 roku objął katedrę na uniwersytecie w Innsbrucku. W przeciwieństwie do swojego znakomitego poprzednika pogłębiał on badania w dyplomatyce, nie skupiając się wyłącznie na badaniu ogólnie przyjętych form kancelaryjnych, a próbując zrozumieć i rozpoznać kontekst historyczny funkcjonowania dokumentu. Brygida Kürbis podobnie, w odniesieniu do postępowania badawczego Sickla uznała, że „doskonalenie metod nauk pomocniczych aż do wręcz mikroskopijnej precyzji w oderwaniu od konstrukcji historiograficznych - w okresie zresztą, kiedy wszelkie nurty dziejowe chętnie rozpatrywano oddzielnie i autonomicznie - wiodło nieuchronnie do mikrografii, będącej pewnego rodzaju zafałszowaniem rzeczywistej sytuacji, z której źródło historyczne wypłynęło. Toteż wielkie znaczenie miało przesunięcie Fickera, polegające na przeniesieniu metody genetycznej na grunt krytyki źródłowej. Długo wszakże przeważał tu formalny punkt widzenia, mało liczący się $\mathrm{z}$ wiecznie zmiennym przebiegiem procesów dziejowych i z ludźmi, discrimen veri ac falsi obejmowało czysto zewnętrznie i mechanicznie stosunek źródła do norm prawnych, kancelaryjnych, literackich"46. W zgodzie z koncepcją Hirscha-Piveca twierdziła Kürbis, że choć „,w wielu podręcznikach [...] trafiają się do dziś takie sformułowania, że dana nauka pomocnicza »usamodzielniła się«. Jest to naturalnie sprzeczność. Będąc wciąż pomocniczą i jak się od niedawna mówi podstawową (Grundwissenschaften w miejsce Hilfswissenschaften) obsługuje nasze badanie tylko na poziomie heurezy i krytyki formalnej (zewnętrznej i wewnętrznej) to jest gromadzenia źródeł i ich sprawdzania. Nic więcej. To co jest ponad tym jest cząstką historii faktów i procesów dziejowych" "47. Kürbisówna poszła nawet dalej. Za austriackim specjalistą od dyplomatyki Heinrichem Fichtenauem ${ }^{48}$ twierdziła, że twórczy udział nauk pomocniczych historii w badaniach historycznych polega nie na ,dalszej ich specjalizacji erudycyjnej, ale - paradoksalnie - w jej unicestwieniu. Tak np. dyplomatyka powinna wejść zgoła do historii piśmiennictwa, sfragistyka i heraldyka do historii symboli i do historii poglądów itp. Możliwości interpretacyjnych dla tekstów, obrazów przedmiotów, obyczaju i gestu jest bez liku"49. Dla Kürbisówny nauki pomocnicze historii stanowiły więc element wszechstronnej historii kultury, na którą składały się takie jej dziedziny jak historia idei, ikonologia czy historia piśmiennictwa ${ }^{50}$. Nie powinny być jej zdaniem traktowane jako wyspecjalizowane techniki badawcze, mogące dążyć do usamodzielnienia się.

44 K. Pivec, Die Stellung der Hilfswissenschaften in der Geschichtswissenschaft, ,Mitteilungen des Österreichischen Instituts für Geschichtsforschung“ 1942, t. 54, z. 1-2, s. 6-7.

45 Ibidem, s. 5.

46 B. Kürbis, Nowsze badania niemieckie..., s. 387.

47 B. Kürbis, Źródło w historycznych dociekaniach Gerarda Labudy, w: J. Dobosz (red.), Naukowe dzieło Profesora Gerarda Labudy, Wydawnictwo Naukowe UAM, Poznań 2006, s. 37.

48 H. Fichtenau, Zur Lage der Diplomatik in Österreich, w: idem, Beiträge zur Mediävistik. Ausgewählte Aufsätze, t. 2, Hiersemann, Stuttgart 1977, s. 1-17.

49 B. Kürbis, Metody źródtoznawcze wczoraj i dziś, w: eadem, Cztery eseje..., s. 110-111.

50 Por. E. Skibiński, Projekt źródtoznawstwa..., s. 20. 


\section{Historia a filologia}

W rozwoju koncepcji metodycznych z zakresu nauk pomocniczych historii Brygida Kürbis szczególną rolę przypisywała filologii, widząc w niej, co podkreślała zwłaszcza w późniejszych pracach, potencjał dla badań historycznych. Miało na to zapewne wpływ jej zaplecze erudycyjne, jakie uformowała w okresie studiów w Niemczech. W tym czasie nie umilkły jeszcze echa sporu o metodę, a podstawę warsztatową dla mediewistów nadal stanowiła kapitalna zasada historyzmu, uznająca metodę historyczną za sprawniejsze narzędzie analizy tekstu niż metody filologiczne. Brygida Kürbis zwłaszcza na początku swojej drogi naukowej traktowała metodę filologiczną jako skierowaną wyłącznie na formalizm. Stąd ostra krytyka pracy Curtiusa, ale i apologetów jego poglądów, w tym Karla Piveca. Ten ostatni swojej fascynacji książką Europäisches Literatur und lateinisches Mittelalter dał wyraz we wspomnianym już wykładzie wygłoszonym na uniwersytecie w Insbrucku, pisząc wręcz o filologizacji metody mediewistycznej ${ }^{51}$. Zdaniem Kürbis ,nie ulega wątpliwości, że dzisiejsza filologia średniowieczna może przybrać kierunek dla dalszych badań niezmiernie płodny. Przyniesie on jednakże owoce tylko wówczas, gdy nie będziemy odrywali analizy stylu i języka od konkretnego podłoża historycznego, którego dane źródło było wytworem"52. Co dla Brygidy Kürbis charakterystyczne - argumentację, w której uzasadnił Pivec swoje uznanie dla pracy Curtiusa, uczona kwituje w bardzo zwięzłej wypowiedzi: „Zainteresuje nas na tym miejscu szczególnie omówiona tu metoda filologiczna w zastosowaniu do źródeł średniowiecznych. Burzenie starych ram czasu i przestrzeni w historiografii oraz zrywanie ze statyką pojęć ma na tym odcinku pracy historyka poważne konsekwencje. Od zdynamizowania wyobrażeń o procesie historycznym niewielki już krok do zrelatywizowania semantyki”. Bez prześledzenia tekstu Piveca trudno jest zrozumieć, co Kürbisówna chciała wyrazić w tych trzech zdaniach. Odniosła się w nich do szeroko ujętej w tekście tego uczonego nowej koncepcji pojmowania czasu w historii. Pivec użył tu metafory sznura pereł, w którym poszczególne kulki symbolizują fakty historyczne i, jak w metodzie genetycznej, następują po sobie w linearnym układzie. Tym samym oddalone od siebie na sznurze perły są jak fakty i wydarzenia z odległych sobie epok. Według Piveca z takim pojmowaniem czasu współczesna mu historiografia definitywnie zerwała. Czas nie jest już wyłącznie linearny, co oddaje choćby pojęcie kontynuacji. Zdaniem Piveca takie podejście zburzyło jednak i stare ramy przestrzeni, która dzięki Toynbee'emu przestała być w historiografii europocentryczna. Kürbis nie przystaje jednak bezkrytycznie na tak żywiołowe zerwanie ze statyką pojęć. Niebezpieczeństwa upatruje w zbyt pobieżnym podejściu do analizy dziejów, zbyt łatwym i efemerycznym łączeniu faktów, czasem bezpodstawnie, a więc w powierzchownym formalizmie. $Z$ kolei do relatywizacji semantyki prowadzi nieuchronnie założenie Piveca, że skoro w dalszym ciągu mamy zbyt małe pojęcie o znaczeniu słów i kategorii łaciny średniowiecznej, być może nigdy nie zdołamy dokonać ekwiwalentnych przekładów dzieł z tego okresu ${ }^{53}$.

51 K. Pivec, Geschichtswissenschaft von heute..., s. 332.

52 B. Kürbis, Nowsze badania niemieckie..., s. 388.

53 K. Pivec, Geschichtswissenschaft von heute..., s. 332. 
Oszczędne w słowach streszczenie poglądów Piveca i nacisk na krytykę jego entuzjazmu wobec pracy Curtiusa w mojej opinii nie jest spowodowany wyłącznie konwencją pisarską Brygidy Kürbis. Austriacki uczony wyraził bowiem w swoim tekście opór wobec materializmu historycznego w historiografii. Tego wątku jednak Kürbis w ogóle nie podjęła. Z kolei z wywodów Piveca na temat jednostronności materializmu historycznego wynika jego podejście do rekonstrukcji historycznej - Brygidzie Kürbis już bardzo bliskie. Źródło w tym ujęciu musi być rozpatrywane w kontekście, w którym powstało, z dokładnym zrozumieniem czasów, z jakich pochodzi. Kürbis kładła przy tym nacisk na uświadomienie sobie, że autor tworzył zawsze $\mathrm{w}$ określonym środowisku, które go kształtowało i które na niego wpływało. To wszystko tworzyło ów osad społeczny dziejów, bo człowiek funkcjonuje jako istota społeczna. Czy można się w tym dopatrywać wpływów marksistowskich? Zdecydowanie nie. Tego typu koncepcje są znacznie starsze, by wspomnieć chociaż Georga Wilhelma Friedricha Hegla i jego stwierdzenie, że każdy jest dzieckiem swoich czasów. Z kolei na gruncie metody historycznej przedmiot historii - człowiek, jako istota działająca społecznie, pojawia się w niemieckich historiozofiach już na początku XX wieku, by znów wspomnieć choćby podręcznik Ernsta Bernheima.

\section{Brygida Kürbis wobec Martina Heideggera}

Na koniec pozostawiłam wątek dotyczący wpływu Martina Heideggera na poglądy teoretyczne Brygidy Kürbis. Studiując we Fryburgu Bryzgowijskim, uczęszczała na wykłady Heideggera, na temat którego wygłosiła nawet krótki referat podczas powojennych studiów w Poznaniu ${ }^{54}$. Zasadne wydaje się zatem pytanie, czy jeden z najwybitniejszych niemieckojęzycznych filozofów XX wieku wpłynął na koncepcje teoretyczne Brygidy Kürbis. Odpowiedź pozytywna wynika nie tylko z intuicyjnych założeń. W dwóch tekstach dotyczących źródłoznawstwa Kürbis, przywołując Heideggera, za przełomowy element jego filozoficznych dociekań uznaje koncepcję opisaną w Sein und Zeit, wedle której „dwoistość podmiot - przedmiot wytłumaczył jako rozszczepienie głębszej struktury bytowej. Kartezjańskie »myślę więc jestem« filozof ten obrócił w »jestem więc myślę«." Innymi słowy, rozdzielenie podmiotu poznającego i przedmiotu poznania (opozycja binarna u Lévi-Straussa) prowadzić musiało do interpretacyjnej stagnacji i postawy ignorabimus, ponieważ kantowska tradycja nie zakładała przejścia między tymi dwoma członami. Konsekwencją takiego podejścia jest założenie: ,ja” jako poznająca i świat poznawany istniejemy osobno. Heidegger rozbił to myślenie. W jego koncepcji przedmiot poznania nie istnieje bez podmiotu poznającego. Tekst może istnieć, bo jest czytany, w przeciwnym wypadku nie istnieje.

Dla Kürbis koncepcja Heideggera ma przełomowe znaczenie dla nowszych osiągnięć interpretacyjnych, w tym hermeneutyki, jako ,sztuki odkrywania wieloznaczności tekstów". Myślenie tymi właśnie heideggerowskimi kategoriami pobrzmiewa w jej krytyce pracy Jerzego Topolskiego pt. Historyk i źródła, próba dynamicznej charakterystyki źródeł historycznych ${ }^{55}$. Kürbis pisze, że „Jerzy Topolski korzystnie ocenił nasze

54 R. Witkowski, Brygida Kürbis, s. 20.

55 J. Topolski, Historyk i źródła: próba dynamicznej charakterystyki źródel historycznych, w: idem, Marksizm i historia, Państwowy Instytut Wydawniczy, Warszawa 1977, s. 42-75. 
dzisiejsze umiejętności »kreowania nowych źródeł historycznych«, co dokonuje się przez stawianie im coraz to nowych pytań" ${ }^{56}$. Takie jednak podejście Topolskiego jest możliwe tylko przy uwzględnieniu starej kantowskiej zasady rozdziału podmiotu poznającego i przedmiotu poznania. Przypomnijmy, że w kolejnych pracach Topolski pójdzie jeszcze dalej i uzna, iż historyk nie rekonstruuje dziejów, a jedynie je konstruuje, ponieważ nie ma dostępu do minionej przeszłości, bo ona już nie istnieje. Kürbis odpowiada na to następująco: „można jednakże przemiany metodyczne w pracy nad źródłami określać nie od strony podmiotu tj. poznającego ale przedmiotu poznawanego, a więc uznawać je za współzależne od poszerzania przedmiotu naszych badań. Posługiwanie się terminem »kreowanie źródeł«, nawet z zastrzeżeniem że dzieje się to tylko w sferze epistemologicznej, wiąże się z pewnym ryzykiem. Może bowiem sugerować, że historia ma ambicje nie tyle odtwarzania dziejów (a więc poznawcze), ile ich przetwarzania (czyli dorabiania dziejom treści których nie mają)". Po czym dodaje po heideggerowsku: „Wszystko co dla badacza stanowi źródło historyczne, istnieje obiektywnie".

\section{Podsumowanie}

Na potrzeby tego artykułu przeprowadziłam jedynie cząstkową analizę księgozbioru Brygidy Kürbis. Jego znakomita część znajduje się obecnie w Bibliotece Instytutu Kultury Europejskiej UAM, gdzie dotarła w 2003 roku. Po śmierci uczonej jej rodzina zdecydowała się sprzedać księgozbiór Bibliotece Uniwersyteckiej UAM. W tym celu Rafał Witkowski sporządził spis książek obejmujący 1664 woluminy, który stał się później podstawą inwentarza bibliotecznego, wykorzystywanego po dziś dzien' ${ }^{57}$. Ostatecznie uczelnia poznańska zakupiła w sumie 1472 woluminy, które w ciągu dwóch lat zostały opracowane przez Bibliotekę Uniwersytecką UAM, a następnie decyzją rektora przekazane do ówczesnego Collegium Europejskiego ${ }^{58}$. Oprócz zbioru książek, gromadzonych w małym mieszkaniu, limitowanego niewielką powierzchnią kawalerki Brygidy Kürbis, należały do niej również woluminy zgromadzone w Zakładzie Źródłoznawstwa i Nauk Pomocniczych Historii, znajdujące się tam do dzisiaj. Systematyczna analiza księgozbioru zapewne rzuciłaby światło na metodykę jej pracy naukowej. Trzeba jednak pamiętać, że jego zestaw musiał z konieczności, z powodu skromnych warunków mieszkaniowych, ulegać zmianie. Książki wówczas przez Kürbisównę niewykorzystywane trafiały zapewne do biblioteki instytutowej bądź pracowników zakładu.

Podsumowując dotychczasowe wnioski uważam, że Brygida Kürbis kształtowała swoje poglądy na metodykę i koncepcję źródłoznawstwa rozpoczynając od pomysłów niemieckojęzycznych badaczy w tym zakresie. W końcu zaplecze erudycyjne wyniosła ze studiów w Niemczech. W rozmowach z jej uczniami - Danutą Zydorek i Edwardem

\footnotetext{
56 B. Kürbis, Metody źródłoznawcze wczoraj i dziś, s. 105.

57 Informacje zawdzięczam Kierownik Biblioteki Instytutu Kultury Europejskiej UAM w Poznaniu Małgorzacie Matczak, która przejmowała zasób w 2003 roku.

58 Niewielka część książek pozostała w Poznaniu, w celu uzupełnienia zasobów Biblioteki Uniwersyteckiej UAM.
} 
Skibińskim często przewijało się stwierdzenie, że na półce pani profesor stał zawsze egzemplarz bernheimowskiego Lehrbuch der historischen Methode und der Geschichtsphilosophie, do którego podchodziła $\mathrm{z}$ wielkim uznaniem ${ }^{59}$. Jest wielce prawdopodobne, że z tej pracy pochodziła definicja autentyczności źródła, wyrażająca się w dwóch podstawowych pytaniach: 1. Ist die Quelle wirklich das, wofür sie sich ausgibt? 2. Ist die Quelle wirklich das, wofür wir sie bisher hielten? i przyjmowana przez Kürbis w pracy badawczej $^{60}$. Nie oznacza to jednak, że przyjmowała teorię metodyki historycznej wykształconej w środowisku niemieckojęzycznych badaczy bezkrytycznie ${ }^{61}$. O ile stanowiła ona dla niej punkt wyjścia do dalszego formułowania myśli teoretycznej, to z całą pewnością na niej nie poprzestała. W tekstach Kürbis widoczny jest np. wpływ koncepcji semiotycznych, przejawiających się w traktowaniu każdego źródła jako tekstu. W swojej bibliotece posiadała np. antologię prac szkoły tartuskiej poprzedzonej przedmową Stefana Żółkiewskiego z 1975 roku $^{62}$. Rok wydrukowania pracy jest tu o tyle ważny, że z drugiego jej wydania zniknął artykuł Aleksandra Piatigorskiego na temat analizy tekstu jako typu sygnału oraz napisany wspólnie z Jurijem Łotmanem artykuł pt. Tekst i funkcja.

Teoria źródłoznawstwa Brygidy Kürbis nie miała sobie podobnej. Była to oryginalna koncepcja, którą uczona rozwijała w całym swoim życiu naukowym. Zbudowała system kategorii, którymi posługiwała się niezmiennie od lat pięćdziesiątych XX wieku. Do tego dodajmy, że mimo wielkiego respektu dla języka ojczystego termini technici swojej koncepcji źródłoznawstwa często zastępowała pojęciami właśnie w języku niemieckim, bynajmniej nie dlatego, że uznawała ich przewagę nad rodzimymi. Wpisywało się to raczej w dialog kultur, których była częścią i co pozwalało jej na wypracowanie własnego stanowiska i twórczy rozwój swoich pomysłów badawczych.

\footnotetext{
59 Tę informację raz jeszcze potwierdziłam przed publikacją artykułu - nie przeprowadziłam jak dotąd systematycznych wywiadów na temat Brygidy Kürbis z jej uczennicami i uczniami.

60 Por. E. Bernheim, Lehrbuch der historischen Methode..., s. 330.

${ }_{61}$ W swojej bibliotece miała na przykład pracę Karla Jacoba, Quellenkunde der deutschen Geschichte im Mittelalter wydanie berlińskie z roku 1943. O ile zapewne przyjmowała jego definicję Quellenkunde jako etapu pracy historyka następującego po Quellenkritik, jego wywody na temat historii politycznej Brygida Kürbis z całą pewnością odrzucała. Swój egzemplarz z odręcznym podpisem „Kürbisówna B.” podarowała Bibliotece Seminarium Historycznego Uniwersytetu Poznańskiego, o czym świadczy odcisk pieczętny przystawiony na s. 2, obecnie egzemplarz znajduje się w Bibliotece Wydziału Historii UAM, sygn. Sa 310/1.

${ }^{62}$ Semiotyka kultury, wybór i oprac. E. Janus, M.R. Mayenowa, Państwowy Instytut Wydawniczy, Warszawa 1975; książka z odręcznym podpisem „B. Kürbis” na s. 1, egzemplarz obecnie znajduje się w Zakładzie Źródłoznawstwa i Nauk Pomocniczych Historii WH UAM.
} 


\begin{abstract}
A Dialogue Between Academic Cultures. Brygida Kurbis's Theoretical Ideas of Historical Methods in the Context of the German-Language Reflection upon the Practice of History

In this paper, I attempt to answer the question - how the ideas of German-speaking historians influenced Brigida Kurbis's concepts of the theory of history and historical methodology. I focus on the categories elaborated by her, that are fundamental to the researcher in the field of historical method, such as source studies (fontology) as well as auxiliary sciences of history.
\end{abstract}

Keywords: Brygida Kurbis, fontology, auxiliary sciences of history, methodology. 